\title{
Entrepreneurship as a Mechanism to Strengthen Rural Communities
}

\author{
Ignacio Ortiz Betancourt, María del Carmen Meza Téllez, Patricia Margarita Villar Sánchez, \\ Leidy Margarita López Castro and Jorge Samuel Berdón Carrasco
}

\section{ABSTRACT}

\begin{abstract}
Entrepreneurship has positioned itself as one of the main goals of both public and private agencies. This topic has been linked to urban areas population, marginalizing different groups and sectors, including the inhabitants of the rural areas have been included, which, usually considered by their lower income and social welfare, due to their inability to access sources of employment and services. Then, this research parts from a theoretical review of rural entrepreneurship and subsequently, explores the results from the application of a research instrument, focused on the perception of a group of rural tourism entrepreneurs was measured about the scope of their projects, pointing out the faced barriers and the gains that have been produced in their communities.
\end{abstract}

Keywords: entrepreneurial culture, social entrepreneurship, small businesses, rural enterprises, entrepreneurs in tourism sector.

\author{
Submitted : March 5, 2021 \\ Published : March 26, 2021 \\ ISSN: $2507-1076$ \\ DOI: $10.24018 / \mathrm{ejbmr} .2021 .6 .2 .800$ \\ Ignacio Ortiz Betancourt* \\ Faculty of Administration (Veracruz) \\ Universidad Veracruzana, Mexico. \\ (e-mail: igortiz@uv.mx) \\ María del Carmen Meza Téllez \\ Faculty of Administration (Veracruz) \\ Universidad Veracruzana, Mexico. \\ (e-mail: cmeza@uv.mx) \\ Patricia Margarita Villar Sánchez \\ Faculty of Administration (Veracruz) \\ Universidad Veracruzana, Mexico. \\ (e-mail: pvillar@uv.mx) \\ Leidy Margarita López Castro \\ Faculty of Administration (Veracruz) \\ Universidad Veracruzana, Mexico. \\ (e-mail: leilopez@uv.mx) \\ Jorge Samuel Berdón Carrasco \\ Faculty of Administration (Veracruz) \\ Universidad Veracruzana, Mexico. \\ (e-mail: jberdon@uv.mx) \\ *Corresponding Author
}

\section{INTRODUCTION}

The global economic panorama at the beginning of the twenty-first century has shown a marked restriction of the labor market, which complicates the insertion of the economically active or qualified population to obtain a formal job; In addition to the above, [1] mentions that not only is the shortage of jobs worrisome but also the degradation of the conditions offered to its occupants since in 2018, close to 3.3 million employees worldwide experience losses in their level of material well-being, financial security, equal opportunities and therefore, of the conditions that allow increasing their human development. In other words, more and more individuals enter the labor market under conditions that do not allow them to improve their living conditions but rather offer their skills in exchange for unattractive, poorly paid jobs with little or no social guarantees. To reverse this marked negative trend in the international context, [2] highlight the importance of productive development policies (PDP) to take advantage of technological change and thus achieve inserting Latin America into the model of the economy of innovation and knowledge. In addition, the need to incorporate the emerging needs of the different productive sectors into the plans of the educational system is highlighted, promoting the development of competencies to reduce the gap between labor supply and demand [2]. Similarly, [3] affirms that the stabilization process of the global economy prevents experiencing accelerated growth rates, which has caused an increase in inequalities and a low generation of jobs, therefore, the Sustainable Development Goals (SDGs) consider that promoting economic growth, productivity and innovation are tasks that must be prioritized globally, which requires the design and implementation of effective policies that promote the business culture and the entrepreneurial spirit. However, the strategies to promote the entrepreneurial spirit should not be generated in a homogeneous way, since they must respond to specific needs of the region or of the interest groups. For this reason, it is common to find policies in favor of entrepreneurship in rural and urban areas, or aimed at supporting specific groups such as women, the elderly, immigrants, among others. Regarding the classification of entrepreneurship by type of area, [4] affirm that social entrepreneurship represents a viable option for the rural environment, which is characterized by a series of social imbalances, little competitiveness in business and scarce supply. In addition to the above, the [5] highlights that poverty within the rural sphere in Latin America increased by two million individuals, a situation that had not been 
registered during the last ten years. In addition, it emphasizes that between 2014 and 2016, the population indicators in poverty and extreme poverty grew in the region, reaching levels of $48.6 \%$ and $22.5 \%$, respectively.

Furthermore, the study of rural entrepreneurship is linked to the issue of development or well-being of rural areas or communities; In this sense, [6] at the end of the twentieth century mentioned the close relationship between rural development and the entrepreneurial spirit and, especially, the importance of entrepreneurs as agents of change, capable of promoting the development of less favored areas. Likewise, [6] highlights the interest that at that time aroused the creation of rural companies given their ability to generate jobs and thus boost the local economy and boost social welfare. In this way, the role that entrepreneurship plays in rural communities is observed, acquiring a strategic role as a mechanism to promote development. However, for this scenario to be viable, the participation of the State, the private sector and educational institutions is required, so that effective strategies can be designed in favor of these ends. In addition to the above, [7] address this issue from the perspective of the tourism sector, for which they affirm that entrepreneurs play an important role in the maintenance of rural tourism and the formulation of sustainable strategies, being the engine of local development These premises acquire special interest in the Mexican context, considering that, as mentioned by [8], the tourism sector contributes $8.8 \%$ of the gross domestic product (GDP) of our country, produces about 4 million direct jobs and generates a favorable balance in the sector balance above 11,000 million US dollars. However, it also highlights that, despite the dynamism of the Mexican tourism sector, in the five main states in this area about $27 \%$ of its inhabitants are in a situation of poverty, which leads to another series of evils or lags in education, health and employment. In addition, this adverse scenario extends to the conditions of the homes of these individuals, which lack or have deficient basic services or do not have sufficient economic resources to satisfy their food needs [8]. Based on the above, the objective of this work is to analyze the effect of tourism projects developed by a group of rural entrepreneurs, to investigate their impact on the local economy and community well-being.

\section{RESEARCH METHODS}

\section{A. Methodology}

This is a mixed exploratory study, since it addresses a subject that has been scarcely reviewed in the context of the State of Veracruz de Ignacio de la Llave (Mexico) based on quantitative and qualitative research techniques; For this reason, it begins with a review of specialized literature on rural entrepreneurship with emphasis on the tourism field; then, a research instrument was applied to a group of rural tourism entrepreneurs, in order to identify the scope of their projects, as well as their perception of the development of this issue in the national context.

\section{B. Theoretical Framework}

As mentioned by [9], establishing a uniform concept of rural entrepreneurship is still an objective to be achieved since it is subject to the geographical and legal characteristics of a country or region, although it is possible to point out some of its characteristics, among the that highlight their dynamism and involvement in various activities, which go beyond agriculture, which generate self-employment projects in areas where jobs are scarce. However, [9] also associates rural entrepreneurship with the emergence of new companies with a low level of innovation, which are linked to the concept of entrepreneurship out of necessity. Similarly, [10] points out that rural areas still face challenges that require the special attention of policy makers. Thus, three specific concerns are identified. First, job opportunities in primary industries are declining; second, the emigration of young people, together with the immigration of retirees in some places, has produced a significant aging of the population; and finally, most rural areas have difficulties in supplying infrastructure and producer services and investments to support economic development, which is why entrepreneurs have difficulties in starting businesses in the area.

In addition to the above, [11] highlight that tourism represents a mechanism to boost the local economy, since it can trigger the emergence of production chains by involving companies that provide inputs or services necessary for tourism services, underpinning job creation. Similarly, [12] point to rural entrepreneurs as key agents for the generation of jobs and wealth, for which the promotion of an entrepreneurial culture together with programs to fight poverty and creation of jobs are pillars within the communities. On the other hand, [13] point out the difference between the concepts of "entrepreneurship in the rural environment" and "Rural entrepreneur" (rural entrepreneurship); The first includes those for-profit activities, a low level of community involvement and that take advantage of market opportunities, while the second reflects an activity that takes advantage of local resources to generate medium to long-term links, which are more beyond business. In addition, they suggest that rural entrepreneurs could keep their companies operating in the place even when the benefits were unattractive, unlike the first type where mobility plays a transcendental role in search of the maximum level of performance. However, it is emphasized that both types are important and have a significant role in rural development. Regarding the elements that encourage the emergence of rural entrepreneurs, [14] points out that despite the fact that there are a large number of variables that affect the success of rural entrepreneurs, the degree of academic training, the age and family environment; Furthermore, he affirms that a high percentage of individuals located in the range of 31 to 40 years of age decide to venture into this field due to the lack of opportunities to obtain a job or a source of income. In addition, [12] highlight three types of factors: psychological, sociological, and economic. Likewise, they emphasize the role of human qualities and the need to improve levels of well-being as triggers for rural entrepreneurship. Regarding human qualities, some of the most important are the emergence of innovative ideas, organizational capacity, and leadership. Also, environmental conditions such as the ability to obtain physical capital, financing, or the ease of creating businesses are important. 


\section{Field Research}

This In order to identify the perceptions of a group of rural tourism entrepreneurs about the scope of their projects, an instrument of 14 items evaluated with multiple choice responses was applied, divided into three categories: general aspects (items 1-4), project characteristics (items 5-10) and socioeconomic impact (items 11-14). Regarding the sample size, due to the scope of this study, the use of nonprobabilistic sampling by quotas was determined, determining 10 entrepreneurs. Regarding the inclusion criteria, only those entrepreneurs from the State of Veracruz de Ignacio de la Llave (Mexico) were considered, who had an activity directly related to the tourism sector and their scope of operation was limited to the rural area, although they could have some center of contact in urban areas.

\section{Sources of Information}

Data were obtained from questionnaires answered by entrepreneurs through email. The response rate was $100 \%$.

\section{RESULTS}

TABLE I: RESULTS

\begin{tabular}{|c|c|}
\hline & Item \\
\hline \multirow[t]{2}{*}{1} & Age (owner or majority partner) \\
\hline & $18-30: 10 \% ; 31-43: 50 \% ; 44-56: 30 \%, 57$ or more: $10 \%$ \\
\hline \multirow[t]{2}{*}{2} & Sex (owner or majority partner) \\
\hline & Female: $40 \%$; Male: $60 \%$ \\
\hline \multirow[t]{2}{*}{3} & Main activity \\
\hline & Services: $30 \%$, Lodging: $30 \%$, Food and beverages: $40 \%$ \\
\hline \multirow[t]{2}{*}{4} & Years in the market \\
\hline & $\begin{array}{l}1 \text { or less: } 20 \% ; 2-3: 20 \% ; 4-5: 30 \% ; 6-8: 10 \% ; 9-10: 10 \% ; 11 \text { or } \\
\text { more: } 10 \%\end{array}$ \\
\hline \multirow[t]{2}{*}{5} & How did the project started? \\
\hline & $\begin{array}{l}\text { Family (new creation): } 30 \% \text {; Family (succession): } 20 \% \text {; Own } \\
\text { initiative: } 40 \% \text {; Transference: } 10 \%\end{array}$ \\
\hline \multirow[t]{2}{*}{6} & What was the main reason behind the project? \\
\hline & $\begin{array}{l}\text { Obtain a source of income: } 40 \% \text {; Contribute to the community: } \\
30 \% \text {; Improve the family income: } 30 \%\end{array}$ \\
\hline \multirow[t]{2}{*}{7} & What was the main source of financing? \\
\hline & Own: $40 \%$; Family: $50 \%$; Private banking: $10 \%$ \\
\hline \multirow[t]{2}{*}{8} & Did you develop a business plan? \\
\hline & Yes: $60 \%$; No: $40 \%$ \\
\hline \multirow[t]{2}{*}{9} & $\begin{array}{l}\text { Did you obtain any type of resource / training from the public or } \\
\text { private sector? }\end{array}$ \\
\hline & Yes: $30 \%$, No: $70 \%$ \\
\hline \multirow[t]{3}{*}{10} & $\begin{array}{l}\text { What has been the main obstacle to the development of the } \\
\text { project? }\end{array}$ \\
\hline & $\begin{array}{l}\text { Obtain financing: } 40 \% \text {; Hiring the right staff: } 30 \% \text {; Positioning } \\
\text { the }\end{array}$ \\
\hline & company: $20 \%$; Other: $10 \%$ \\
\hline \multirow[t]{2}{*}{11} & $\begin{array}{l}\text { Without considering the owner, how many direct jobs has the } \\
\text { project generated? }\end{array}$ \\
\hline & $1: 20 \% ; 2$ a $3: 30 \% ; 4$ a $5: 20 \% ; 6$ or more: $30 \%$ \\
\hline \multirow[t]{2}{*}{12} & $\begin{array}{l}\text { Has the project benefited the emergence of other support } \\
\text { companies / activities? }\end{array}$ \\
\hline & Yes: $30 \%$; No: $40 \%$; I do not know: $30 \%$ \\
\hline \multirow[t]{2}{*}{13} & $\begin{array}{l}\text { From your point of view, how do you rate the progress of your } \\
\text { project? }\end{array}$ \\
\hline & $\begin{array}{l}\text { Significant: } 10 \% \text {; significant: } 40 \% \text {; neutral: } 20 \% \text {; insignificant: } \\
20 \% \text { Very significant: } 10 \%\end{array}$ \\
\hline \multirow[t]{3}{*}{14} & $\begin{array}{l}\text { In your opinion, how would you evaluate the effect of your } \\
\text { project on the community? }\end{array}$ \\
\hline & $\begin{array}{l}\text { Very significant: } 10 \% \text {; significant: } 30 \% \text {; neutral: } 40 \% \text {; } \\
\text { insignificant: }\end{array}$ \\
\hline & $20 \%$ Very significant: $0 \%$ \\
\hline
\end{tabular}

Based on Table I, the important role that the family plays in the projects are observed, since they contribute valuable elements for their creation and financing; Furthermore, the largest number of individuals claim to have developed a business plan and not have had training from public or private organizations. On the other hand, the main age range among those surveyed was 31 to 43 years, representing $50 \%$ of the sample. This result is similar to that reported by [14] who also highlights the need for individuals to undertake to obtain a source of income, a similar situation that was presented in this research. In addition, the contribution of projects in the generation of direct jobs is highlighted, since all respondents indicated that at least one job has been created, which agrees with the observations of [12]; however, a significant trend towards the creation of production chains is not reflected since $30 \%$ indicated they did not know if their company has supported the emergence of other organizations or support activities and another $40 \%$ stated that they have not contributed in this aspect, which differs from the premises presented by [11]. Together, the difficulty of entrepreneurs to access financing for the correct operation of projects is notable, although $40 \%$ affirmed that these have advanced significantly and another $10 \%$ described the progress as very significant. Similar figures were found when inquiring about the impact of organizations on communities, highlighting the fact that no entrepreneur claimed that it had been null.

\section{CONCLUSION}

The development of this work allowed to address a littleexplored issue in the context of the State of Veracruz de Ignacio de la Llave (Mexico), detecting a positive trend of tourism entrepreneurship in rural areas, mainly in the creation of direct jobs. However, it is necessary to investigate in greater detail the effect of projects on the generation of productive chains and their contribution to community wellbeing. Therefore, it is necessary to strengthen the research instrument and then replicate this study in a larger sample, to detect those factors that influence the success of rural tourism entrepreneurs.

\section{REFERENCES}

[1] International Labor Organization. (2019). MUNDO PERSPECTIVAS SOCIALES EMPLEO. Retrieved from https://www.ilo.org/wcmsp5/groups/public/---dgreports/---dcomm/--publ/documents/publication/wcms_670569.pdf.

[2] OECD/CAF/CEPAL. (2018). Perspectivas económicas de América Latina 2018 Repensando las instituciones para el desarrollo. https://doi.org/10.1787/leo-2018-es.

[3] UNDP. (n.d.). Objetivo 8: Trabajo decente y crecimiento económico PNUD. Retrieved May 10, 2019, from https://www.undp.org/content/undp/es/home/sustainabledevelopment-goals/goal-8-decent-work-and-economic-growth.html.

[4] Martínez, S., \& Rodríguez, L. (2013). Emprendedurismo social en México: hacia un modelo de innovación para la inserción social y laboral en el ámbito rural. Estudios Agrarios, 103-120.

[5] United Nations. (2018). Crece pobreza rural en América Latina Retrieved from http://www.onunoticias.mx/america-latina-se-estaolvidando-de-sus-campesinos/.

[6] Petrin, T. (1994). Entrepreneurship as an economic force in rural development. In Seventh FAO/REU International Rural Development Summer School, Herrsching, Germany, 8-14 September 1994 Retrieved from http://www.fao.org/3/W6882e/w6882e02.htm.

[7] Sharif, N., \& Lonik, K. 'Azam. (2017). Sustaining the Entrepreneurship in Rural Tourism Development. International 
European Journal of Business and Management Research www.ejbmr.org

Journal of Multicultural and Multireligious Understanding, 4(6), 31. https://doi.org/10.18415/ijmmu.v4i6.122.

[8] Ministry of Tourism. (2019). Estrategia Nacional De Turismo 20192024 Tendrá Un Sentido Democrático: Miguel Torruco. Ciudad de México. $\quad$ Retrieved from https://www.gob.mx/sectur/prensa/estrategia-nacional-de-turismo2019-2024-tendra-un-sentido-democratico-miguel-torruco.

[9] Cabus, P. (2009). Who is the rural entrepreneur?Retrieved from https://core.ac.uk/download/pdf/34490297.pdf.

[10] OECD. (2005). Working Party on Territorial Policy in Rural Areas PLACE-BASED POLICIES FOR RURAL DEVELOPMENT LAKE BALATON, HUNGARY (CASE STUDY). Retrieved from http://www.oecd.org/cfe/regional-policy/35856049.pdf.

[11] Soare, I., Dobrea,N. C. R. C., \& Nastase, M. (2018). THE RURAL TOURIST ENTREPRENEURSHIP -NEW OPPORTUNITIES OF CAPITALIZING THE RURAL TOURIST POTENTIAL IN THE CONTEXT OF DURABLE DEVELOPMENT. European Journal of Sustainable Development. https://doi.org/10.14207/ejsd.2017.v6n3p231.

[12] Chatterjee, R., Mukherjee, D., Chakraborty, G., \& Deb, A. (2017) Factors Influencing Growth of Rural Entrepreneurship in Tripura: A Socio -Economic Perspective. IMS Manthan (The Journal of Innovations) (Vol.

12). https://doi.org/10.18701/imsmanthan.v12i01.10335.

[13] Korsgaard, S., \& Tanvig, H. W. (2015). Rural entrepreneurship or entrepreneurship in the rural -between place and space. International Journal of Entrepreneurial Behaviour and Research. https://doi.org/10.1108/IJEBR-11-2013-0205.

[14] Chakraborty, D. (2014). Socio-Economic Determinants of Growth of Rural Entrepreneurship in Sonitpur Distric of Assam-an Emprical Study. Journal of Behavioural Economics, Finance, Entrepreneurship, Accounting and Transport, 2(1), 26-34. 